\title{
Upaya pencegahan sindrom metabolik dan obesitas melalui perubahan pola eating habits, screen-based activities serta peningkatan aktivitas fisik pada anak dan remaja
}

\author{
Eka Febri Zulissetiana $^{1 *}$, Budi Santoso ${ }^{1}$, Syifa Alkaf ${ }^{1}$, Puji Rizki Suryani ${ }^{2}$, Andra Kurnianto ${ }^{3}$ \\ ${ }^{1}$ Bagian Fisiologi dan Fisika Medik, Pendidikan Dokter, Fakultas Kedokteran, Universitas Sriwijaya \\ ${ }^{2}$ Bagian Ilmu Kedokteran Jiwa, Pendidikan Dokter, Fakultas Kedokteran, Universitas Sriwijaya \\ ${ }^{3}$ Bagian Gizi, Pendidikan Dokter, Fakultas Kedokteran, Universitas Sriwijaya \\ E-mail: dr.eka_1902@yahoo.com
}

\begin{abstract}
Abstrak
Obesitas pada masa anak dan remaja dianggap sebagai salah satu masalah kesehatan yang cukup serius di abad 21 ini. Obesitas menjadi perhatian serius karena prevalensi yang semakin meningkat setiap tahunnya. Pemberian pemahaman yang benar kepada masyarakat serta pelatihan kepada para kader Posyandu merupakan cara yang tepat guna mencegah peningkatan kasus obesitas baru. Kegiatan pengabdian masyarakat ini dilakukan di Kota Palembang, Sumatera Selatan. Penyuluhan tentang obesitas dilakukan kepada 87 orang remaja dan 45 orang dewasa. Pelatihan dan pendampingan cara mengukur IMT juga dilakukan pada 10 orang kader Posyandu. Evaluasi terhadap keberhasilan kegiatan dilakukan dengan menggunakan pertanyaan acak kepada peserta sebelum dan sesudah kegiatan. Setelah kegiatan pengabdian masyarakat, sebagian besar peserta dan kader Posyandu memahami mengenai obesitas pada anak dan remaja serta cara mencegahnya. Dari kegiatan pengabdian masyarakat ini, dapat disimpulkan bahwa penyuluhan dan pelatihan dapat digunakan untuk meningkatkan pengetahuan dan keterampilan masyarakat dan kader dalam mengenali dan mencegah obesitas pada anak dan remaja
\end{abstract}

Kata kunci: Obesitas, Anak, Remaja, Sindrom metabolik, Pencegahan

\begin{abstract}
Prevention of metabolic syndrome and obesity through modification of eating habits, screen based activities and physical activities in children and adolescents. Obesity in childhood and adolescence is considered as one of the serious health problems in the 21st century. Obesity is a serious concern because the prevalence is increasing every year. Providing correct understanding to the community and training for Posyandu cadres is an appropriate way to prevent an increase in new cases of obesity. This community service activity was carried out in the city of Palembang, South Sumatra. Counseling about obesity is done to 87 teenagers and 45 adults. Training and assistance on how to measure BMI are also carried out for 10 Posyandu cadres. An evaluation of the success of the activity is carried out using random questions to the participants before and after the activity. After community service activities, most Posyandu participants and cadres understand about obesity in children and adolescents and how to prevent it. From this community service, it can be concluded that counseling and training can be used to improve the knowledge and skills of the community and cadres in recognizing and preventing obesity in children and adolescents.
\end{abstract}

Keywords: Obesity, Children, Adolescent, Metabolic Syndrome, Prevention 


\section{PENDAHULUAN}

Definisi berat badan berlebih dan obesitas pada anak dan remaja didasarkan pada nilai rentang berat badan suatu individu berdasarkan tinggi badannya yang dikenal dengan Indeks massa tubuh (IMT) yang dibandingkan dengan populasi anak dengan jenis kelamin dan usia yang sama dengan menggunakan kurva CDC. Obesitas adalah suatu istilah yang digunakan untuk menunjukkan suatu kondisi tingginya rentang IMT. Obesitas menggambarkan tingginya jumlah penimbunan lemak yang dapat menyebabkan berbagai masalah kesehatan. ${ }^{1}$

Berat badan berlebih dan obesitas pada anak berisiko berlanjut ke masa dewasa, dan merupakan faktor risiko terjadinya berbagai penyakit metabolik dan degeneratif yang salah satunya adalah sindrom metabolik. Sindrom metabolik adalah suatu kelompok gejala abdominal, dislipidemia, hiperglikemia, dan hipertensi. Sindrometabolik pada anak dan remaja menyebabkan kekhawatiran terjadinya peningkatan prevalensi penyakit kardiovaskular di masa mendatang pada kelompok usia tersebut. ${ }^{2,3}$

Obesitas pada masa anak dan remaja dianggap sebagai salah satu masalah kesehatan yang cukup serius di abad 21 ini. Obesitas menjadi perhatian serius karena prevalensinya semakin meningkat setiap tahunnya. Secara global, 1 dari 6 anak berusia 5-17 tahun mengalami berat badan berlebih dan obesitas. Pada tahun 2016, jumlah anak penderita obesitas mencapai 124 juta orang dengan 216 juta anak mengalami berat badan berlebih. Jumlah ini mengalami peningkatan 10 kali lipat dari 11 juta orang pada tahun $1975 .{ }^{4} \mathrm{Di}$ Indonesia, prevalensi obesitas pada anak juga terus meningkat setiap tahun. Berdasarkan data Riskesdas 2010 dan 2013 menunjukkan prevalensi kegemukan dan obesitas pada anak sekolah (6-12 tahun) bertambah lima kali lipat dari 1,4 menjadi 9,2\%. Sumatera Selatan termasuk dalam salah satu dari sebelas propinsi dengan prevalensi obesitas berada di atas

prevalensi nasional (11,6\%). ${ }^{5,6}$ Penelitian di Jakarta (2011) menunjukkan bahwa komorbiditas dislipidemia (52\%) dan resistensi insulin (35,6\%) sudah ditemukan pada anak 
usia 5-9 tahun yang superobes dengan prevalensi sindrom metabolik $34 \%$ pada 50 remaja obesitas berusia 10-19 tahun. ${ }^{3}$

Obesitas dan berat badan terutama dipengaruhi oleh faktor lingkungan seperti pola makan dan gaya hidup. Kurangnya pengetahuan dan salah persepsi tentang kebutuhan makanan dan nilai makanan juga merupakan merupakan salah satu faktor yang mempengaruhi status gizi seseorang. ${ }^{7}$ Pendampingan dan penyuluhan merupakan pendekatan edukatif yang diharapkan menghasilkan perilaku individu atau masyarakat yang diperlukan dalam meningkatkan perbaikan pangan dan status gizi. ${ }^{8}$

Oleh karena itu perlu dilakukan penyuluhan pada masyarakat tentang obesitas dan sindrom metabolik pada anak dan remaja serta pelatihan dan pendampingan lanjutan kepada para kader Posyandu dan puskesmas dalam mendefinisikan obesitas dan sindrom metabolik berdasarkan perhitungan IMT, lingkar pinggang dan kurva CDC. Sehingga diharapkan dapat meningkatkan pengetahuan dan kesadaran masyarakat tentang definisi, penyebab, komplikasi dan pencegahan obesitas dan sindroma metabolik.

\section{TINJAUAN PUSTAKA}

Obesitas adalah kelebihan berat badan sebagai akibat dari penimbunan lemak tubuh yang berlebihan. ${ }^{9}$ Secara umum obesitas terjadi karena gangguan keseimbangan antara asupan energi dengan keluaran energi (energy expenditures), sehingga terjadi kelebihan energi yang selanjutnya disimpan dalam bentuk jaringan lemak. Kelebihan energi tersebut dapat disebabkan oleh asupan energi yang tinggi atau keluaran energi yang rendah. Asupan energi tinggi disebabkan oleh konsumsi makanan yang berlebihan, sedangkan keluaran energi rendah disebabkan oleh rendahnya metabolisme tubuh, aktivitas fisik, dan efek termogenesis makanan yang ditentukan oleh komposisi makanan.

Lemak memberikan efek termogenesis lebih rendah (3\% dari total energi yang dihasilkan lemak) dibandingkan karbohidrat (6-7\% dari total energi yang dihasilkan karbohidrat) dan protein (25\% dari total energi yang dihasilkan protein). Sebagian besar 
gangguan homeostasis energi ini disebabkan oleh faktor idiopatik (obesitas primer atau nutrisional), sedangkan faktor endogen (obesitas sekunder atau non-nutrisional, yang disebabkan oleh kelainan hormonal, sindrom, atau defek genetik) hanya mencakup kurang dari $10 \%$ kasus. $^{10}$

Faktor penyebab kegemukan dan obesitas pada remaja dan anak bersifat multifaktorial. Faktor genetik, faktor lingkungan dan faktor psikologis merupakan faktorfaktor yang berkontribusi pada perubahan keseimbangan energi dan berujung pada kejadian obesitas. Obesitas dan berat badan terutama dipengaruhi oleh faktor lingkungan. Pengaruh faktor lingkungan terutama terjadi melalui ketidakseimbangan antara perilaku makan (eating habits), aktivitas fisik dan berkembangnya pola sedentary lifestyle.5,11,12

Kebiasaan makan yang buruk merupakan salah satu penyebab penting terjadinya kelebihan berat badan dan obesitas di kalangan anak-anak dan remaja. Sebagian besar remaja masih belum memenuhi rekomendasi diet saat ini yaitu lima komponen (karbohidrat, protein, lemak, serat dan susu) per hari. Asupan gula, terutama melalui minuman yang dimaniskan dengan gula, menjadi perhatian khusus dalam hubungannya untuk kelebihan berat badan dan obesitas karena berkontribusi pada peningkatan asupan energi secara keseluruhan.

Kurangnya aktivitas fisik juga merupakan faktor penyebab terjadinya kegemukan dan obesitas pada anak sekolah. Keterbatasan lapangan untuk bermain dan kurangnya fasilitas untuk beraktivitas fisik menyebabkan anak memilih untuk bermain di dalam rumah. Tingkat aktivitas fisik pada umumnya sangat rendah pada anak-anak dan remaja di semua negara. Waktu yang dihabiskan untuk menjadi aktif secara fisik menurun pada masa remaja. Aktivitas fisik adalah penentu utama pengeluaran energi, karena memiliki pengaruh positif mendasar terhadap keseimbangan energi dan kontrol berat badan. Aktivitas fisik teratur pada anak-anak dan remaja adalah penting untuk pencegahan obesitas dan mendukung remaja obesitas untuk mengelola berat badan mereka. 
Rekomendasi global saat ini menyatakan bahwa anak muda yang berusia 5-17 tahun harus melakukan setidaknya 60 menit aktivitas fisik intensitas sedang setiap hari. Aktivitas fisik termasuk bermain, permainan, olahraga, transportasi, pekerjaan rumah tangga, rekreasi, pendidikan jasmani dan latihan terstruktur dan dapat dilakukan dalam konteks kegiatan keluarga, sekolah atau masyarakat. ${ }^{11}$ Kemajuan teknologi berupa alat elektronik saat ini seperti video games, playstation, televisi dan komputer menyebabkan berkembangnya pola sedentary lifestyle pada anak. Hampir 60\% waktu anak dihabiskan dengan duduk. Pola sedentary lifestyle pada anak juga sejalan dengan pola screenbased activities yang juga sangat berhubungan dengan perilaku makan seperti mengonsumsi makanan ringan (snacking).5,11

Tatalaksana obesitas meliputi berbagai strategi seperti modifikasi gaya hidup, intervensi farmakologis dan terapi bedah yang harus disesuaikan dengan usia dan perkembangan anak untuk mempertahankan berat badan tetapi tidak menghambat pertumbuhan dan perkembangan. Penerapan pola makan seimbang dan peningkatan aktivitas fisik pada anak sekolah bukanlah hal yang mudah. Diperlukan dukungan dari orang tua, guru, tenaga kesehatan, dan pihak lainnya. Berkaitan dengan hal itu maka upaya penanggulangan ini harus menjadi komitmen nasional yang harus dilakukan secara sistematis dan terpadu serta berkelanjutan.

\section{METODE}

Kegiatan ini dilaksanakan di Kelurahan Srijaya, Kecamatan Alang-alang lebar, Kota Palembang Provinsi Sumatera Selatan. Khalayak sasaran dari kegiatan ini adalah para remaja dan orang dewasa dengan jumlah 132 orang, serta 10 orang kader kesehatan setempat. Kegiatan ini dilakukan dengan melibatkan dosen dan mahasiswa dari Fakultas Kedokteran Universitas Sriwijaya. Metode kegiatan yang akan dilakukan adalah sebagai berikut:

a. Penyuluhan, dilakukan dengan ceramah menggunakan alat bantu berupa power point dan leaflet yang akan dibagikan masing-masing ke peserta; juga dilakukan diskusi dengan masyarakat tentang bagaimana selama ini paradigma mengenai berat badan berlebih, pola 
makan anak-anak di rumah maupun di sekolah selama ini serta penjelasan mengenai obesitas, sindrom metabolik dan cara mencegah dan mengatasi melalui perubahan pola hidup.

b. Demonstrasi dan pendampingan yaitu memberikan pelatihan dengan melibatkan secara langsung tenaga dan kader kesehatan serta mahasiswa cara mengukur status gizi dengan IMT dan lingkar pinggang dan menginterpretasikannya di kurva pertumbuhan CDC.

c. Pemantauan, untuk mengetahui keberhasilan dari kegiatan yang telah dilaksanakan oleh dosen dan mahasiswa

Penilaian keberhasilan penyuluhan dilakukan dengan cara memberikan pertanyaan acak kepada peserta dan para kader untuk menilai pemahaman mereka sebelum dan sesudah kegiatan.

\section{HASIL DAN PEMBAHASAN}

Kegiatan ini diikuti oleh 87 orang siswa, 45 orang dewasa dan 10 orang kader Posyandu setempat. Sebelum dilakukan penyuluhan, dinilai terlebih dahulu pengetahuan awal dari para peserta dengan diberikan beberapa pertanyaan dan pendapat para peserta mengenai obesitas pada anak dan remaja. Dari hasil diskusi awal dengan peserta diketahui bahwa banyak mitos yang salah mengenai obesitas pada anak dan remaja. Sebagian besar peserta masih menganggap obesitas pada anak dan remaja bukan suatu hal yang harus ditangani dan tidak menimbulkan komplikasi yang serius. Selain itu juga dinilai pengetahuan awal dari para kader Posyandu mengenai cara menilai status gizi dengan IMT masih dinilai kurang.

Kegiatan kemudian dilanjutkan dengan penyuluhan selama 30 menit dengan menggunakan bantuan media power point terkait definisi obesitas dan sindrom metabolik pada anak dan remaja, penyebab, bahaya, komplikasi dan morbiditas yang mungkin timbul jika anak dan remaja mengalami obesitas. Selain itu, peserta juga mendapat penjelasan mengenai cara mencegah dan mengurangi obesitas melalui perubahan perilaku eating 
habits, peningkatan aktivitas fisik dan mengurangi pola screenbased activity (sedentary lifestyle). Setelah selesai penyuluhan, terlihat antusiasme para peserta bertanya dan berdiskusi mengenai topik yang telah diberikan.

Kegiatan pendampingan juga diberikan pada kader Posyandu mengenai keterampilan mengukur status gizi dengan menggunakan IMT dan ukuran lingkar perut serta menginterpetasikan IMT pada anak dan remaja berdasarkan kurva pertumbuhan CDC. Materi pendampingan pada kader hampir sama dengan masyarakat awan antara lain tentang pengertian obesitas, penyebab, ciri-ciri, bahaya dan cara mencegah obesitas pada anak dan remaja. Khusus kepada kader Posyandu diperkenalkan dengan alat-alat yang diperlukan dalam menilai status antropometri seperti timbangan bayi, timbangan remaja dan dewasa, pita ukur dan stature meter serta cara untuk menghitung IMT dan kemudian memplotnya pada kurva CDC/WHO. Setelah pemaparan tentang metode tersebut, tim melibatkan peserta dalam sesi demonstrasi. Peserta dibagai menjadi 2 kelompok masingmasing terdiri dari 2-3 orang dengan 3 tim instruktur. Tim terdiri dari dosen Fakultas Kedokteran dan mahasiswa tingkat akhir pendidikan dokter umum Universitas Sriwijaya.
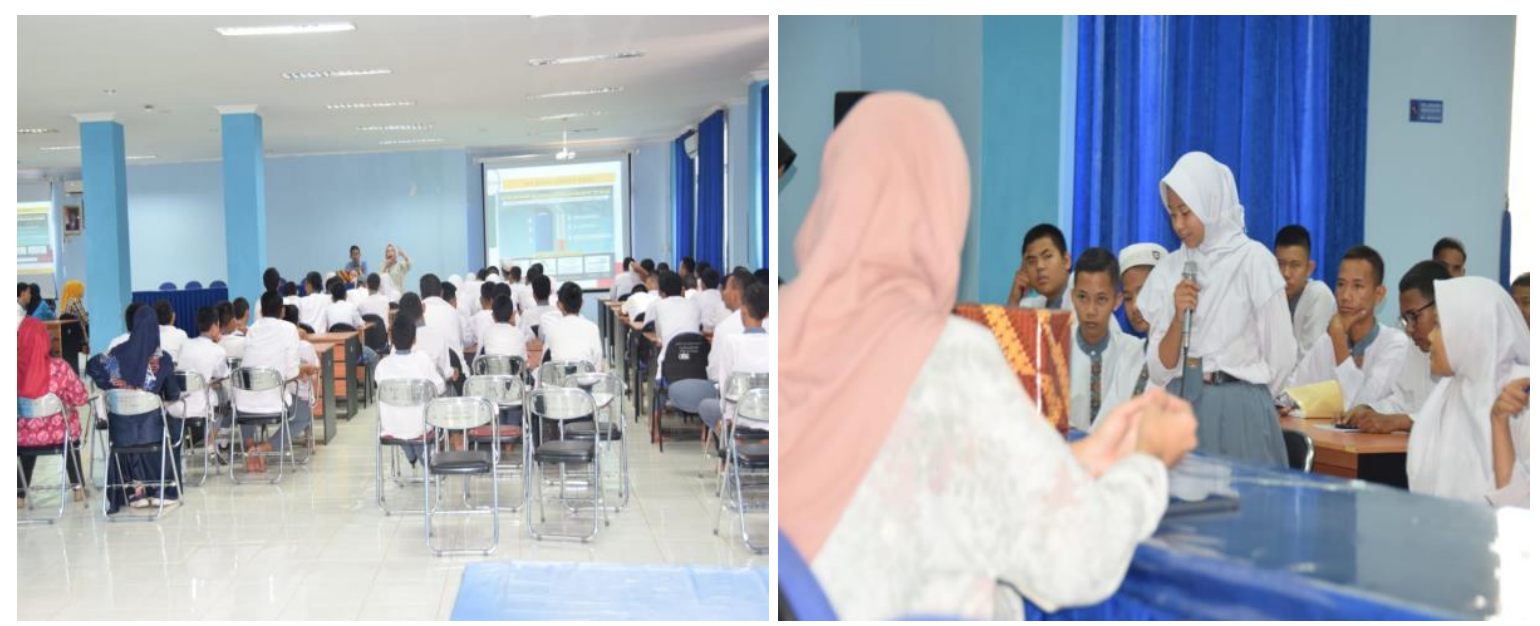

Gambar 1. Suasana kegiatan pengabdian masyarakat pada remaja

(a) penyuluhan (b) diskusi dan evaluasi 


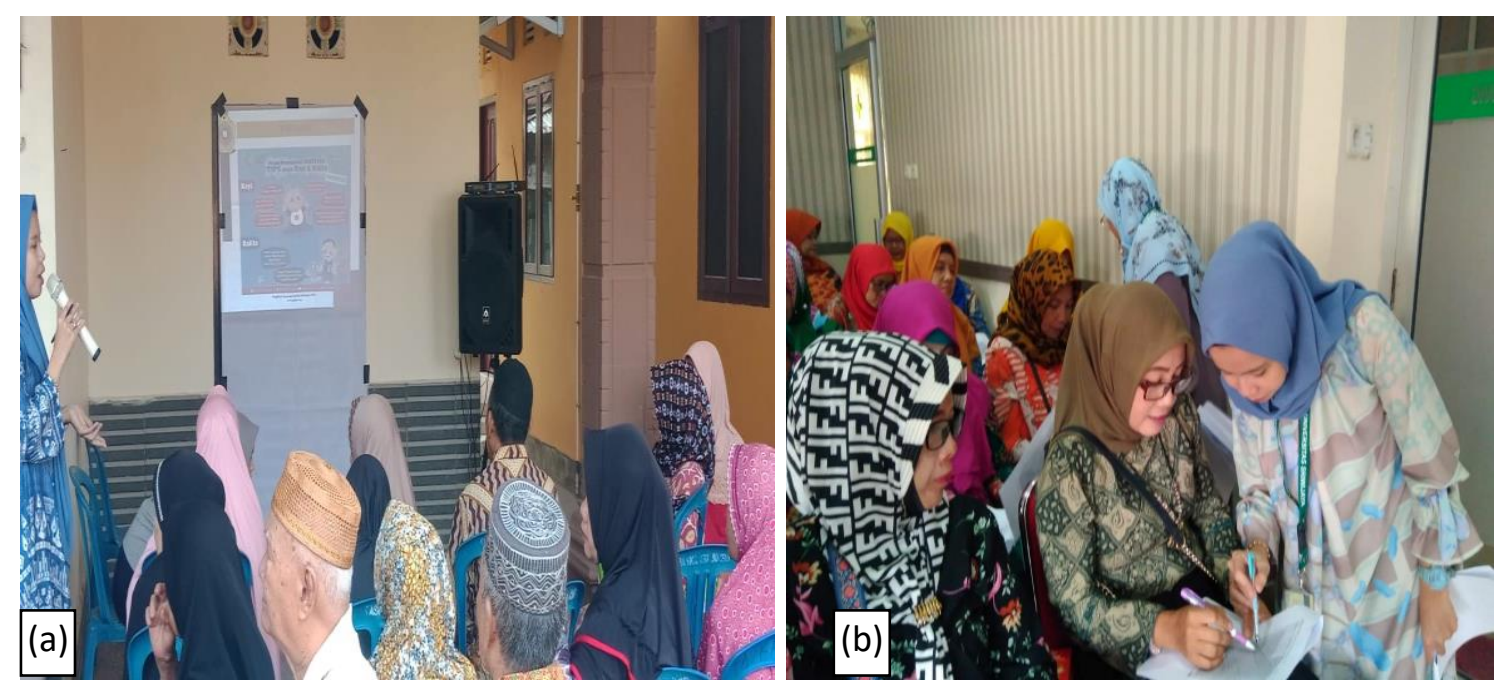

Gambar 2. Suasana Kegiatan Pengabdian Masyarakat pada

(a) orang tua (b) kader posyandu

Sasaran kegiatan pada pengabdian masyarakat ini adalah para remaja, orang tua dan kader posyandu. Pemilihan sasaran kegiatan pada pengabdian masyarakat ini dimulai pada masa anak dan remaja karena pencegahan dan penanggulangan obesitas melalui pendidikan kesehatan sebaiknya dimulai sejak usia anak-anak atau remaja. Anak sekolah merupakan sasaran strategis dalam perbaikan gizi masyarakat karena sedang mengalami pertumbuhan fisik dan mental dalam rangka menunjang kehidupannya nanti. Penyuluhan gizi sebagai bagian dari pendidikan gizi di sekolah dapat dilakukan karena anak mempunyai pemikiran terbuka dibandingkan dengan orang dewasa serta pengetahuan yang diterima dapat menjadi dasar bagi pembinaan kebiasaan makannya. ${ }^{8}$ Kegiatan ini juga melibatkan orang tua sebagai sasaran dikarenakan masalah gizi pada anak dipengaruhi juga oleh peran keluarga.

Orang tua khususnya ibu membentuk pola konsumsi pangan dalam keluarga, terutama dalam pembentukan kebiasan makan anak dalam keluarga. Orang tua bertanggung jawab terhadap kesehatan anak dan harus mengambil inisiatif untuk memberikan semua jenis makanan yang dianggap dapat memenuhi gizi anak terutama orang tua yang berpendapatan tinggi yang memiliki peluang lebih besar untuk memilih jenis makanan. Adanya peluang tersebut mengakibatkan pemilihan jenis dan jumlah 
makanan tidak lagi berdasarkan kebutuhan dan pertimbangan kesehatan tetapi lebih mengarah pada pertimbangan praktis (fast food). ${ }^{13}$ Kader Posyandu juga dilibatkan dalam kegiatan ini sehingga transfer pengetahuan dan perubahan perilaku dapat dilakukan secara kontinu.

Untuk menilai pemahaman peserta tentang obesitas pada anak dan remaja dilakukan evaluasi dengan menggunakan beberapa pertanyaan. Sebagian besar peserta dapat menjawab pertanyan dengan baik dan merangkum materi yang telah disampaikan. Hal ini menunjukkan bahwa ada peningkatan pengetahuan pada peserta tentang cara mengenali dan mencegah obesitas pada anak dan remaja.

Teknik penyuluhan masyarakat memang dapat dilakukan sebagai upaya memberikan pengetahuan atau keterampilan bila dilaksanakan dengan baik. Oleh karena itu, kegiatan seperti dapat terus dilakukan dengan peserta yang berbeda dan dengan modifikasi berbagai alat peraga.

\section{KESIMPULAN}

Setelah kegiatan pengabdian masyarakat, sebagian besar peserta memiliki pengetahuan dalam mengenali dan mencegah obesitas pada anak dan remaja. Peningkatan keterampilan dalam mengukur dan menginterpretasi status gizi pada anak dan remaja juga ditunjukkan oleh kader posyandu setelah proses penyuluhan dan pendampingan. Kegiatan penyuluhan dan demonstrasi dapat dilakukan untuk meningkatkan pengetahuan dan keterampilan masyarakat dalam mengenali dan mencegah obesitas pada anak dan remaja.

\section{Ucapan Terima Kasih}

Terima kasih kepada Rektor Universitas Sriwijaya, Dekan Fakultas Kedokteran Universitas Sriwijaya dan Bapak Moerdoko (Tokoh Masyarakat, Kelurahan Srijaya, Kecamatan Alang-

al (a) lebar, Kota Palembang) yang telah memfasilitasi dan/atau membantu terlaksananya kegiatan pengabdian masyarakat ini. 


\section{Referensi}

1. Centers for Disease Control and Prevention. Defining childhood overweight and obesity [internet]. 2010. Retrieved April 6, 2019 from http://www.cdc.gov/obesity/childhood/defining.html.

2. Haris S, Tambunan T. Hipertensi pada sindrom metabolik. Sari pediatri, 2016;11(4), 25763.

3. Indonesia ID. Diagnosis, tata laksana dan pencegahan obesitas pada anak dan remaja. UKK Nutrisi dan Penyakit Metabolik Ikatan Dokter Anak Indonesia. Jakarta: BP IDAI. 2014.

4. World Health Organization. Adolescent obesity and related behaviours: trends and inequalities in the WHO European Region 2002-2014. 2017

5. Kementerian Kesehatan RI. Pedoman Pencegahan dan Penanggulangan Obesitas pada Anak Sekolah. Jakarta: Kemenkes RI. 2012.

6. Noer ER, Kustanti ER, Fitriyanti AR. Perilaku gizi dan faktor psikososial remaja obes. Jurnal Gizi Indonesia (The Indonesian Journal of Nutrition), 2018;6(2): 109-113.

7. Merisya M, Darwin E, Iryani D. Hubungan tingkat pengetahuan ibu tentang gizi dengan kejadian obesitas anak di sd islam al-azhar 32 padang. Jurnal Kesehatan Andalas, 2015;4(1).

8. Riswanti I. Media Buletin dan Seni Mural dalam Upaya Meningkatkan Pengetahuan tentang Obesitas. Journal of Health Education, 2016;1(1).

9. Husnah H. Tatalaksana obesitas. Jurnal Kedokteran Syiah Kuala, 2012;12(2): 99-104.

10. Indonesia ID. Diagnosis dan tatalaksana sindrom metabolik pada anak dan remaja. Jakarta: IDAI, 2014. 2-10.

11. Monasta L, Lobstein T, Cole TJ, Vignerová J, Cattaneo A. Defining overweight and obesity in pre-school children: IOTF reference or WHO standard? Obesity Reviews, 2011;12(4): 295-300.

12. Kurdanti W, Suryani I, Syamsiatun NH, Siwi LP, Adityanti MM, Mustikaningsih D, et al. Faktor-faktor yang mempengaruhi kejadian obesitas pada remaja. Jurnal Gizi Klinik Indonesia, 2015;11(4): 179-190.

13. Mariam DA, Larasati TA. Obesitas anak dan peranan orangtua. Jurnal Majority, 2016;5(5): 161-5. 